\title{
Application of the Tandem Thionium/ $N$-Acyliminium Ion Cascade Toward Heterocyclic Synthesis
}

\author{
Albert Padwa*, Diana M. Danca, John D. Ginn and Stephen M. Lynch \\ Department of Chemistry, Emory University, Atlanta, GA 30322 USA
}

\begin{abstract}
Compostos heterocíclicos estruturalmente diversos podem ser facilmente obitdos através do processo sequencial Pummerer/cicloadição/ ciclização via ion $\mathrm{N}$-acilimínio.

Many structurally diverse heterocyclic compounds can be easily accessed via the domino Pummerer/cycloaddition/ $N$-acyliminium ion cyclization cascade.
\end{abstract}

Keywords: Pummerer reaction, $N$-acyliminium ion, cyclization, heterocycles, alkaloid synthesis, domino, tandem, cascade

The Pummerer rearrangement of sulfoxides with acid anhydrides has been extensively utilized as a method for synthesizing $\alpha$-substituted sulfides ${ }^{1-6}$. The initial step of the reaction involves acylation of the sulfoxide oxygen to form an acyloxy-sulfonium salt (2), thus converting this oxygen to a good leaving group. Removal of a proton from the $\alpha$ carbon with elimination of the acyloxy group generates a thionium ion (3), which is trapped by one of the nucleophilic species present in the reaction medium (Scheme 1). The finding that thionium ions may serve as electrophiles in electrophilic substitution chemistry has greatly extended the synthetic range of the Pummerer reaction ${ }^{4}$. Thus, both inter- ${ }^{7}$ and intramolecular ${ }^{8}$ versions of the process have been used to prepare a wide assortment of compounds. Currently, Pummerer-based transformations are finding widespread application in carbo- ${ }^{9}$ and heterocyclic syntheses ${ }^{10}$ by reaction of the initially generated thionium ions with internally disposed nucleophiles.
As part of our continuing interest in cascade transformations ${ }^{11}$, we have become interested in tandem induced Pummerer processes with the intention of assessing their viability as a general strategy for the synthesis of heterocyclic ring systems ${ }^{12}$. Domino cascade processes belong to a growing family of reactions which allow for the regio- and stereocontrolled formation of several carboncarbon bonds and/or ring systems in a single operation ${ }^{13}$. Cationic reactions that proceed in a domino fashion are featured in the biosynthesis of important natural products, and synthetic applications of both biomimetic and nonbiomimetic cationic cyclizations have been widely developed ${ }^{14}$. Important contributions to this area have also been realized utilizing a combination of anionic, radical, carbenoid, and transition metal-catalyzed processes ${ }^{15}$

While developing a Pummerer approach toward the synthesis of various alkaloid skeletons ${ }^{16}$, we uncovered a versatile amido annulation process based on a consecutive thionium/Mannich ion cyclization sequence (Scheme 2) ${ }^{17}$.

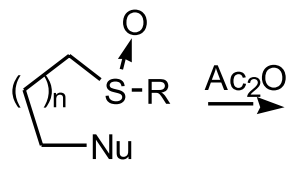

1

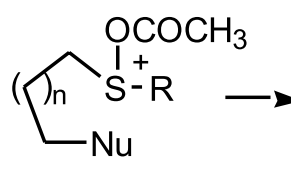

2

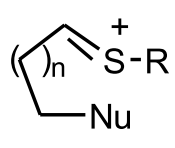

3

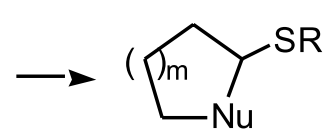

4

Scheme 1.

* e-mail: chemap@emory.edu 
A synthetic method that combines transformations of different reaction types significantly broadens the scope of such procedures in synthetic chemistry.

One of the first systems that we examined in our laboratory involved the Pummerer cyclization of amide $\mathbf{1 0}$ to dihydroindolone $\mathbf{1 1}^{18}$. After some experimentation with known Pummerer promoters, we found that the highest yield of 11 (94\%) was obtained from the reaction of $\mathbf{1 0}$ with 1-(dimethyl-tert-butylsiloxy)-1-methoxyethylene in dry $\mathrm{CH}_{3} \mathrm{CN}$ in the presence of a catalytic amount of $\mathrm{ZnI}_{2}$ (Scheme 3). This reaction, whereby sulfoxides react with O-silylated ketene acetals, was originally studied in some detail by Kita and coworkers as a method for preparing $\alpha$ siloxy sulfides under mild conditions ${ }^{19}$. The mechanism associated with this process involves the generation of a silyloxy sulfonium salt that undergoes subsequent elimination by a highly stereoselective deprotonation of the antiperiplanar $\alpha$ - methylene proton ${ }^{20}$.

The synthetic value of the Pummerer reaction of an amidosulfoxide such as $\mathbf{1 0}$ lies mainly in the subsequent cyclization chemistry of the resulting $\alpha$-thiophenyl lactam.
This led us to study the tandem cyclization cascade of several related amidosulfoxides which possess a $\pi$-bond tethered to the amide nitrogen. The silicon-induced Pummerer reaction of the 2-(3,4-dimethoxyphenyl)-substituted amidosulfoxide 12 proceeded uneventfully to provide the expected indolone $\mathbf{1 3}$ in $\mathbf{7 5 \%}$ yield. Attempts to induce the cyclization of $\mathbf{1 3}$ to isoquinolinedione $\mathbf{1 4}$ proved to be unexpectedly difficult, with variable yields of product being obtained. A survey of diverse Lewis acids was carried out $\left(\mathrm{BF}_{3} \bullet \mathrm{OEt}_{2}, \mathrm{ZnI}_{2}, \mathrm{AlCl}_{3}, \mathrm{TiCl}_{4}\right.$, $\mathrm{MgBr}_{2}$, etc). Among the many Lewis acids employed in this study, $\mathrm{TlCl}_{3}$ in $\mathrm{CH}_{3} \mathrm{CN}$ afforded the highest yield of cyclized product 14 , but only in $50 \%$ yield. We also examined the Pummerer cyclization of sulfoxide 15 which afforded 3hydroxypyrrole $16(50 \%)$ as the thermodynamically most stable tautomer. The formation of this product proceeds by an initial cyclization to afford a 3-pyrrolidinone intermediate which is further oxidized upon standing in the presence of air. The isolation of $\mathbf{1 6}$ clearly indicates that thionium ion cyclization can also occur with acyclic systems (Scheme 4).

When the acyclic amidosulfoxides $\mathbf{1 7}$ and 18 were used, the sequential Pummerer/Mannich cyclization proceeded<smiles></smiles>

5
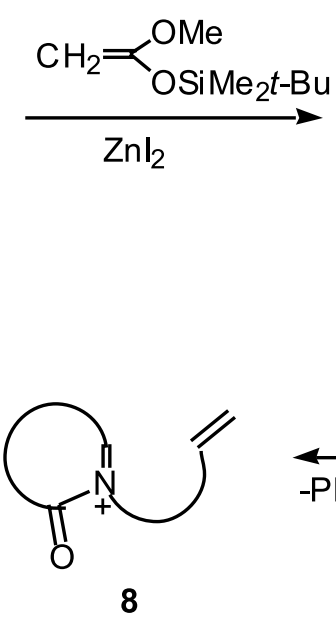

Scheme 2.

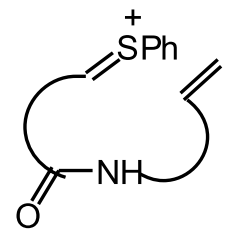

6

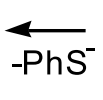<smiles>O=C1CCCCCC([SbH])N2CCCCCCC12[SnH]</smiles>

7

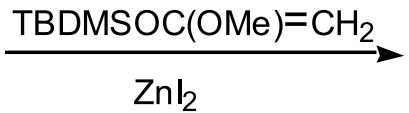


<smiles>CC[As](O)CC(=O)c1ccccc1NC(=O)Cc1ccc(OC)c(OC)c1</smiles>

12

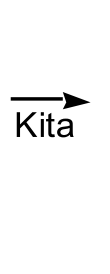<smiles>CCSC1C(=O)c2ccccc2N1C(=O)Cc1ccc(OC)c(OC)c1</smiles>

$13(75 \%)$<smiles>COc1cc2c(cc1OC)C1C(=O)c3ccccc3N1C(=O)C2</smiles>

$14(50 \%)$<smiles></smiles>

15<smiles>CSc1c(O)ccn1C(=O)c1ccccc1</smiles>

$16(50 \%)$

Scheme 4.

in excellent yield. These compounds were easily prepared by addition of thiophenol to the appropriate alkenoic acid $\pi$-bond, and this was followed by reaction of the in situ generated acyl chloride with 3,4-dimethoxyphenethylamine. The silicon-induced Pummerer reaction of these amidosulfoxides was carried out using Kita's conditions ${ }^{19}$ which led to the very clean formation ( $>90 \%)$ of 2-thiosubstituted lactams 19 and 20 . Iminium ion-aromatic $\pi$ cyclization was readily accomplished by treatment of $\mathbf{1 9}$ or 20 with 1.2 equiv of $\mathrm{BF}_{3} \cdot 2 \mathrm{AcOH}$ in $\mathrm{CH}_{2} \mathrm{Cl}_{2}$ at $25{ }^{\circ} \mathrm{C}$ to provide bicyclic lactams $\mathbf{2 1}$ or $\mathbf{2 2}$ in $96 \%$ and $92 \%$ yield, respectively (Scheme 5). A related set of reactions occurred using the indolyl substituted amidosulfoxides $\mathbf{2 3}$ and $\mathbf{2 4}$ which afforded indoles $\mathbf{2 7}$ and $\mathbf{2 8}$ in excellent yield from the initially formed Pummerer products $\mathbf{2 5}$ and $\mathbf{2 6}$.

Since the above examples involve aromatic $\pi$-bond cyclization, we decided to study several systems which possess a simple olefinic tether. We found that treatment of the cyclohexenyl substituted amidosulfoxide $\mathbf{2 9}$ with the tert-butyl O-silylated ketene acetal caused an intramolecular Pummerer-type reaction to give $\alpha$ thiolactam $\mathbf{3 0}$ which was subsequently converted to $\mathbf{3 1}$ upon exposure to $\mathrm{BF}_{3} \cdot 2 \mathrm{AcOH}$ in $54 \%$ overall yield. The homologous amidosulfoxide $\mathbf{3 2}$ also underwent a similar sequence of reactions, first producing $\mathbf{3 3}$ which was subsequently converted into isoquinolinone $\mathbf{3 4}$. Extension of the two-step cyclization sequence to the 3-methylbutenyl substituted amide $\mathbf{3 5}$ was also carried out (Scheme 6).
The silicon-induced Pummerer reaction gave rise to the cyclized pyrrolidinone $\mathbf{3 6}$ in $71 \%$ yield. However, with this system, reaction with $\mathrm{BF}_{3} \cdot 2 \mathrm{AcOH}$ afforded a mixture of several cyclized products that could not be separated by silica gel chromatography. After some experimentation, we found that stirring a sample of thiolactam 36 with dimethyl(methylthio)sulfonium fluoroborate (DMTSF) proceeded smoothly to give 7-hydroxy-7-methylhexahydroindolizin-3-one (37) as the exclusive product in $74 \%$ isolated yield. DMTSF is known to exhibit a remarkable thiophilicity for initiation of cyclization reactions of thioketals by promoting thionium ion formation ${ }^{21}$.This reagent also seems to be able to function as a $N$-acyliminium ion promoter when a $\alpha$-thiophenyl substituted lactam such as $\mathbf{3 6}$ is used.

Our interest in establishing amidosulfoxides as useful building blocks for heterocyclic synthesis prompted us to use the Pummerer methodology for the preparation of a member of the protoberberine alkaloid family ${ }^{22}$. The protoberberines are a large class of natural products typically characterized by a tetracyclic ring skeleton with an isoquinoline core $^{23}$. Considerable efforts have been expended in the study of these molecules for both their synthetic and biological significance. These alkaloids exhibit wide-ranging and important biological activity, including antiinflammatory, antileukemic, and antitumor properties $^{24}$. Most of the synthetic approaches are generally plagued by the non-availability of starting materials, multi- 
<smiles>COc1ccc(CCNC(=O)CCC[SbH](O)c2ccccc2)cc1OC</smiles>

17; $\mathrm{n}=1$

18; $n=2$<smiles>O=C(CCC[Sn+](O)c1ccccc1)NCCc1cn(Cc2ccccc2)c2ccccc12</smiles>

23; $\mathrm{n}=1$ 24; $n=2$<smiles>COc1ccc(CCN2C(=O)CCC2c2ccccc2)cc1OC</smiles>

19; $\mathrm{n}=1(90 \%)$

$20 ; n=2(93 \%)$

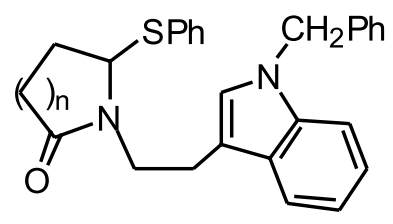

25; $\mathrm{n}=1(72 \%)$

26; $n=2(54 \%)$<smiles>COc1cc2c(cc1OC)C1CCC(=O)N1CC2</smiles>

21; $n=1(96 \%)$

22; $n=2(92 \%)$

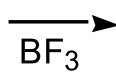<smiles>O=C1CC2C1CN1CCc3c(n(Cc4ccccc4)c4ccccc34)C21</smiles>

27; $\mathrm{n}=1(97 \%)$

28; $n=2(95 \%)$

Scheme 5.<smiles>O=C(CCC[Sb](O)c1ccccc1)NCCC1=CCCCC1</smiles>

29; $\mathrm{n}=1$

32; $\mathrm{n}=2$<smiles>C=C(C)CCNC(=O)CCC[AsH-](O)c1ccccc1</smiles>

35<smiles>CCCCCCC</smiles><smiles></smiles><smiles>C=C(C)CCN1C(=O)CCC1Sc1ccccc1</smiles>

$36(71 \%)$

33; $n=2(54 \%)$<smiles></smiles><smiles>O=C1CCC2C3CCCCC3=CCN12</smiles>

$31 ; n=1(54 \%$

$34 ; n=2(52 \%$

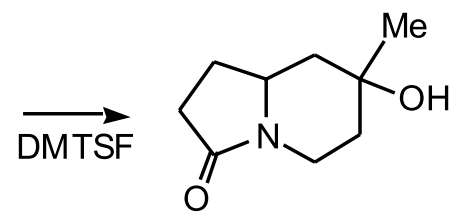

$37(74 \%)$

Scheme 6.

step procedures, and moderate to poor yields ${ }^{25}$. A short synthesis of the berberine derivative $\mathbf{4 1}$ was carried out as depicted in Scheme 7 in order to highlight the method. This particular compound has been isolated from the Oriental shrub Acangelissa gusanlung and given the name gusanlung $\mathrm{D}^{26}$. This berberine is one of a number of alkaloids found in the plant, the stem of which has been used in Chinese folk medicine for many years. Subjection of the easily available amidosulfoxide $\mathbf{3 8}$ to TMSOTf/NEt as the Pummerer initiator afforded 2-thiophenyl lactam 39 in $64 \%$ yield. Interestingly, when the Kita silicon conditions were used to trigger the Pummerer reaction, only enamide $\mathbf{4 0}(85 \%)$ was obtained. The reaction of $\mathbf{3 9}$ with Lewis acids such as $\mathrm{ZnI}_{2}$ resulted in the formation of enamide $\mathbf{4 0}$ in 93 
$\%$ yield. When 40 was exposed to acidic conditions, it was transformed into the berberine derivative $\mathbf{4 1}$ in 55\% yield.

Although the sequential process outlined above proved valuable for a number of substrates, we faced several limitations during our attempts to extend the scope of the reaction toward the synthesis of a number of other alkaloids. Thus, in many of the cases examined, it was necessary to isolate and purify the initially formed 2-phenylthiolactam intermediate before subjecting it to various electrophilic reagents so as to induce the second ring closure. In addition, formation of the $\mathrm{N}$-acyliminium ion intermediate required the use of a strong Lewis acid and, as a result, the yield associated with the cyclization was variable. We reasoned that by replacing the sulfoxide functionality with a thioacetal group, it might be possible to bring about a "onepot" cascade. Indeed, we have found that the desired reaction occurred in high yield when DMTSF was used as the reagent to initiate the process. A typical example involved the DMTSF reaction of the bromoalkenyl substituted amido thioacetals $\mathbf{4 2}$ and $\mathbf{4 3}$ (Scheme 8). When 42 was subjected to the DMTSF conditions followed by an aqueous workup, the initially cyclized product was hydrolyzed to ketolactam 44 in $65 \%$ overall yield. A related set of reactions occurred with amido thioacetal 43 ultimately producing the known octahydroquinolizin-4,8dione $\mathbf{4 5}^{27}$ in $58 \%$ yield. These two examples further demonstrate the facility with which the thionium/iminium ion cascade can occur.

As a further consequence of our interest in domino ringforming reactions using thionium ion precursors, we also examined a new approach toward heterocyclic synthesis that involves a tandem thionium/N-acyliminium ion cyclization strategy as depicted in Scheme 9.

Our initial efforts focused on the cyclization reactions<smiles>O=C(NCCc1ccc2c(c1)OCO2)c1ccccc1CC[AsH2+]c1ccccc1</smiles>

38<smiles>O=C1c2ccccc2CC2c3cc4c(cc3CCN12)OCO4</smiles>

$41(55 \%)$<smiles>CCN(CC)CCN1C(=O)c2ccccc2CC1[Sn]([O-])([O-])[O-]</smiles><smiles>[14CH3]</smiles><smiles>O=c1c2ccccc2ccn1CCc1ccc2c(c1)OCO2</smiles>

$40(85 \%)$

Scheme 7.<smiles>[R]SC([R])CCC(=O)NCCC(=C)Br</smiles>

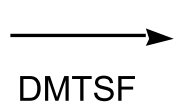

42; $\mathrm{n}=1 ; \mathrm{R}=\mathrm{Et}$ 43; $\mathrm{n}=2 ; \mathrm{R}=\mathrm{Me}$

44; $\mathrm{n}=1$

45; $n=2$ 
of $\alpha$-sulfinylenamides $\mathbf{5 0}$ and $\mathbf{5 2}$. These compounds were conveniently prepared in $60-80 \%$ yield from the condensation of 3,4-dimethoxyphenethylamine with the appropriate aldehyde or ketone followed by reaction of the resulting imine with ethylthioacetyl chloride ${ }^{28}$.Treatment of 50 with 2 equiv of $p$-TsOH in refluxing benzene afforded 51 in $78 \%$ yield (Scheme 10). It is important to note that only one of several possible diastereomers of the fused isoquinoline lactam $\mathbf{5 1}$ was observed under the reaction conditions as indicated by ${ }^{1} \mathrm{H}$ and ${ }^{13} \mathrm{C}$-NMR spectral data.
The stereochemical assignment was unequivocally established by X-ray crystallographic analysis which revealed a syn relationship between the thioethyl, carboethoxy and methyl groups. $\alpha$-Sulfinylenamide $\mathbf{5 2}$ underwent an analogous cyclization affording the fused isoquinoline lactam 53 in $69 \%$ yield.

This cyclization reaction also proceeded with high diastereospecificity and led to a single diastereomer where the methyl and thioethyl groups are on the same side of the ring (NOE). The NOE enhancement between the tertiary<smiles>[R]C=CN(CC[As])CC(=O)[Se]O</smiles>

46<smiles>[R]C1C(SCC)C(=O)N2CCCCCCNC12</smiles>

49
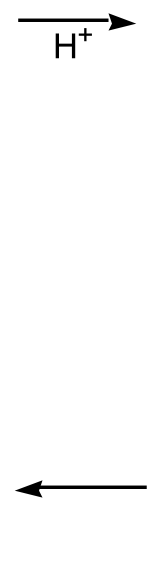

Scheme 9.

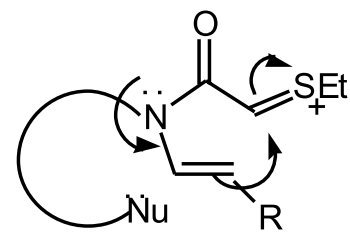

47

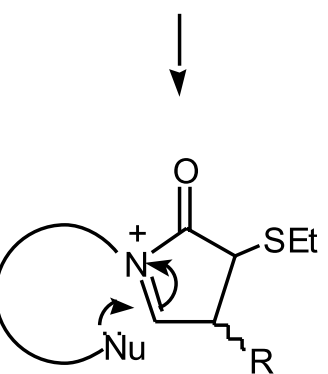

48<smiles>CCOC(=O)C(C)=C(C)N(CCCc1ccc(OC)c(OC)c1)C(=O)C[Si](O)CC</smiles>

50<smiles>CC[Si](=O)CC(=O)N(C=C(C)c1ccccc1)/C=C(\C)[O-]</smiles><smiles>CCOC[C@@]1(C)[C@H](SCC)C(=O)N2CCc3cc(OC)c(OC)cc3[C@]21C</smiles>

51<smiles>[2H][C@@]12c3cc(OC)c(OC)cc3CCN1C(=O)[C@H](SCC)[C@@]2(C)[PH]</smiles> 
hydrogen adjacent to the nitrogen atom of the lactam ring and the vicinal methyl group further defines the stereochemical relationship of the substituent groups present in $\mathbf{5 3}$.

A plausible mechanism which nicely rationalizes the stereochemical results involves initial formation of an $\alpha$ acylthionium ion (i.e., 55) followed by a Nazarov type ${ }^{29}$ $4 \pi$-electrocyclic ring closure which occurs in a conrotatory fashion to give $N$-acyliminium ion 56 (Scheme 11). The final cyclization step proceeds in a stereoselective manner by attack of the proximal aromatic ring from the less hindered side of the iminium ion framework.

Attention was next turned to the acid induced cyclization of the related enamides $\mathbf{5 7}$ and $\mathbf{5 9}$ where the point of attachment of the tethered aromatic ring was switched from nitrogen to carbon. Treatment of $\mathbf{5 7}$ with $p$ $\mathrm{TsOH}$ under identical conditions to that used for the cyclization of $\mathbf{5 0}$ gave $\mathbf{5 8}$ as a single diastereomer in $\mathbf{7 9 \%}$ yield. Likewise, reaction of the indolyl substituted $\alpha$ sulfinylenamide 59 with $p$-TsOH also produced a single crystalline polycycle $\mathbf{6 0}$ in $80 \%$ yield. The structures and stereochemistries of products $\mathbf{5 8}$ and $\mathbf{6 0}$ follow from analysis of their NMR spectroscopic data and their formation is perfectly consistent with the tandem thionium/ iminium ion cascade sequence outlined in Scheme 12.

The reaction of iminium ions with tethered alkenes represents one of the most general methods for the synthesis of alkaloids ${ }^{30}$. Since the previous examples of our tandem
Pummerer/iminium ion cyclization involve aromatic $\pi$ bonds, we decided to study several systems which possess a simple olefinic tether. The well documented reactivity of allylsilanes towards electrophiles ${ }^{31}$ suggested that the acid promoted reaction of sulfinylenamide $\mathbf{6 1}$ should provide access to a bicyclic lactam. Indeed, treatment of $\mathbf{6 1}$ with $p$ TsOH afforded the cyclized product 62 in $61 \%$ yield (Scheme 13). We suspect that the initially formed lactam, which possesses an exocyclic double bond, gets isomerized under the reaction conditions. In light of the successful $\pi$ cyclization of 61, we next examined the Pummerer reaction of $\alpha$-sulfinylenamide $\mathbf{6 3}$ and were pleased to find that tosylate 64 was formed in $80 \%$ yield.

As part of our studies in this area, we have also been interested in another type of Pummerer cascade which we refer to as the domino Pummerer/ cycloaddition/ $\mathrm{N}$ acyliminium ion cyclization cascade. Many structurally diverse heterocyclic compounds can be easily accessed via this method. Several years ago, De Groot and coworkers developed a procedure for butenolide formation in which the key step involves a Pummerer induced cyclization of aldehydic sulfoxides of type $\mathbf{6 5}$ into butenolides 67 (Scheme 14) ${ }^{32}$. It was assumed that the neighboring carbonyl group attacks the initially formed thionium ion to give an oxy-stabilized cation $\mathbf{6 6}$ which loses a proton to generate a 2-thio substituted furan which is subsequently converted to the butenolide upon hydrolysis. On the basis of this transformation, we decided to explore the internal

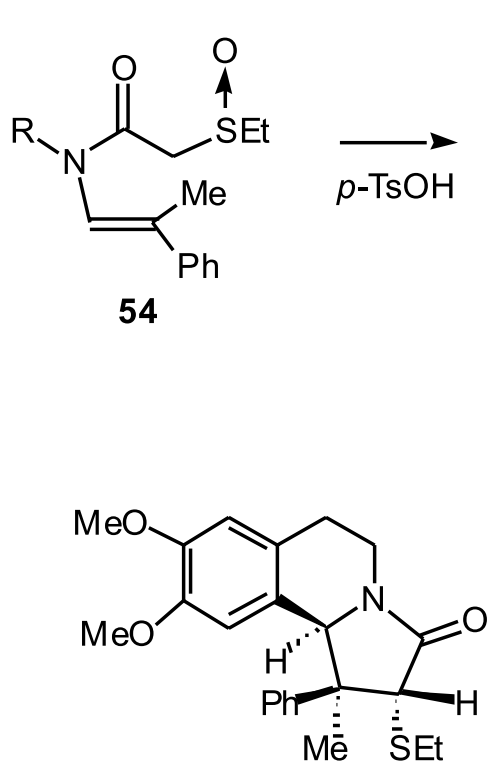

53

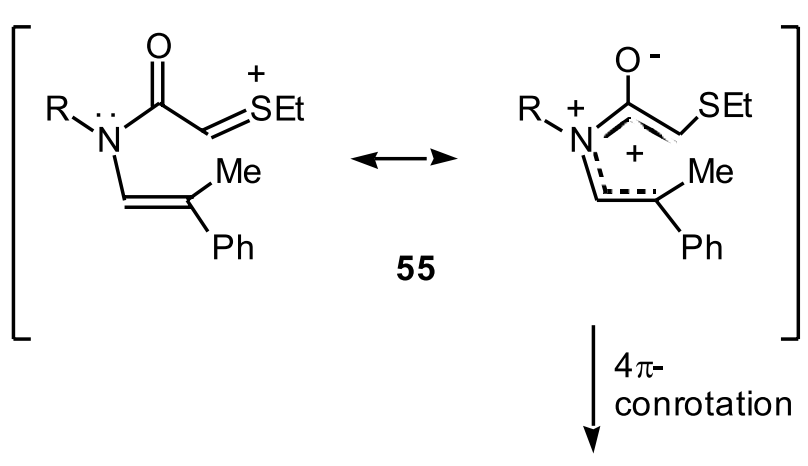

$$
\mathrm{R}=(\mathrm{MeO})_{2} \mathrm{C}_{6} \mathrm{H}_{3} \mathrm{CH}_{2} \mathrm{CH}_{2}
$$

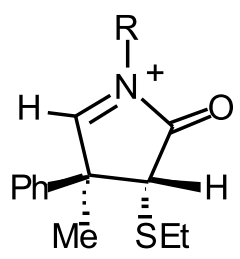

56

Scheme 11. 
<smiles>CC[Si](O)CC(=O)N(Cc1ccccc1)/C(C)=C(\Cc1ccc2c(c1)OCO2)C(=O)OC</smiles><smiles>CC[C@H]1C(=O)N(C)[C@@]2(C)c3cc4c(cc3CC12COC)OCO4</smiles>

58<smiles></smiles>

59

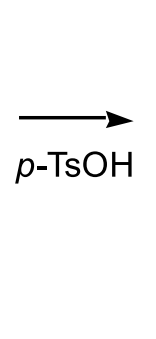

Scheme 12.<smiles>C=C(CC)CC(C(=O)C[Se]O)=C(C)N(Cc1ccccc1)C(=O)CC</smiles>

61

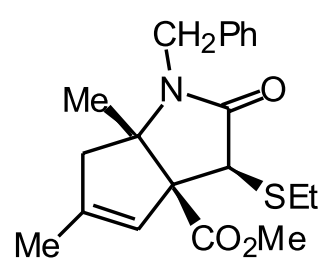

62<smiles>C=CCC/C(C(=O)OC)=C(/C)N(Cc1ccccc1)C(=O)C[Si](O)CC</smiles>

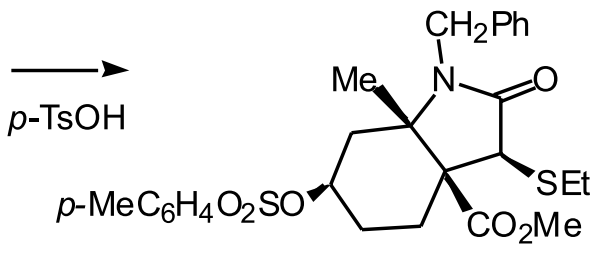

64 
trapping of the Pummerer cation with an adjacent amido carbonyl group as a method to prepare a variety of novel heterocycles. The strategy was first tested on amidosulfoxide 68 (Scheme 15). The $\alpha$-thiocarbocation derived from the Pummerer reaction of $\mathbf{6 8}$ was readily intercepted by the adjacent amido group to produce isobenzofuran 69 as a transient intermediate which underwent a subsequent Diels-Alder cycloaddition with an added dienophile. The resulting cycloadduct $\mathbf{7 0}$ was readily converted to representatives of several types of amino-substituted naphthalene lignans $\mathbf{7 1}^{33}$.

In order to access synthetically more valuable targets, we focused our attention on an intramolecular variation of the domino amido-Pummerer-Diels-Alder reaction sequence. The one-pot intramolecular cascade process occurred smoothly when a carbonyl group was located adjacent to the nitrogen atom of the 2-amino substituted isobenzofuran (Scheme 16) ${ }^{34}$. The intramolecular cycloaddition behavior of the incipient isobenzofurans in response to the presence of a $\mathrm{C}=\mathrm{O}$ group is striking. Five and six ring-membered precursors $\mathbf{7 2}$ and $\mathbf{7 3}$ delivered cyclized products bearing a carbonyl within the newly formed rings in good to excellent yields. Externalization of the $\mathrm{C}=\mathrm{O}$ as in $\mathbf{7 6}$ likewise led to a facile internal cyclization. Removal of the $\mathrm{C}=\mathrm{O}$ functionality, however, suppressed intramolecular cycloaddition in favor of the traditional Pummerer reaction. The reactivity discrepancy can be rationalized in terms of steric effects in the transition states. The incorporation of an amido group is clearly of synthetic advantage as it offers the opportunity to accelerate intramolecular cycloaddition by steric adjustment of ground-state and transition state energies either separately or simultaneously.

Having established the facility with which $N$ acyliminium ions can be formed from the Pummerer reaction of $o$-amido substituted sulfoxides, we next focused our attention on the final cyclization step of the proposed cascade process ${ }^{35}$. In order to avoid the deprotonation<smiles>CC1=C(C=O)CCC(C)C1CO</smiles>

65

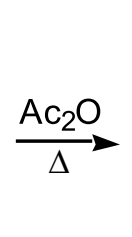<smiles>CC1CCC2=C(C1)C([SbH2])[CH-]O2</smiles>

66

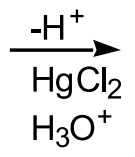

$\mathrm{H}_{3} \mathrm{O}^{+}$<smiles>CC1CCC2=C(C(=O)OC2)C1C</smiles>

67

Scheme 14.<smiles>[R]N([R])C(=O)c1ccccc1C[SH](O)O</smiles>

68

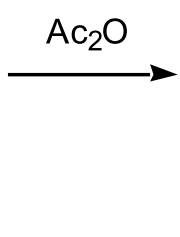<smiles>[R]N([R])c1oc([S-])c2ccccc12</smiles>

$\downarrow A=B$<smiles>[R]N([R])C1=[Te]=C(SCC)c2ccccc21</smiles>

71

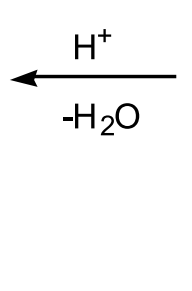<smiles>[R]N([R])C12OCC(CC)(O1)c1ccccc12</smiles>

70

Scheme 15.

(aromatization) step, we prepared sulfoxides $\mathbf{7 8}$ and $\mathbf{7 9}$, each possessing a carbomethoxy group attached to the olefin tether. This substituent was selected not only to prevent deprotonation, but also because the presence of an electron withdrawing group on the double bond enhances [4+2]- cycloaddition based on FMO considerations. $\mathrm{N}$ Acyliminium ion $\mathbf{8 1}$ derived from the internal cycloadduct 80 underwent stereoselective spirocyclization to furnish the cis-3,4-benzoerythrinane $\mathbf{8 2}$ or homoerythrinane derivative $\mathbf{8 3}$ in good yield (Scheme 17). The overall triple cascade sequence represents an efficient one-pot approach towards the erythrinane alkaloid skeleton ${ }^{36}$ in which the spirocyclic ABC skeleton is assembled in a single operation.

A synthesis of ( \pm )-erysotraamidine (93) was undertaken in order to further test the viability of the triple cascade process as an entry into the erythrinane skeleton.

The requisite starting imido-sulfoxide $\mathbf{8 4}$, possessing both a dienophilic and diactivated aromatic $\pi$-tether, was efficiently synthesized from known starting materials. Subjection of $\mathbf{8 4}$ to the Pummerer conditions gave compound 90 as a single diastereomer in $83 \%$ yield. The 
<smiles>C=CCC(=O)N(C)C(=O)c1ccccc1C[SH](O)OCCO</smiles>

72; $n=1$

73; $n=2$<smiles>C=CCCN(C(C)=O)C(=O)c1ccccc1C[SH](O)O</smiles>

76<smiles></smiles>

74; $n=1$

$75 ; n=2$<smiles>CC(=O)Oc1cc2c(c3ccccc13)N(C(C)=O)CC2</smiles>

77

cis A/B ring fusion present in $\mathbf{9 0}$ was unequivocally established by an X-ray crystallographic analysis and is identical to the stereochemical relationship found in the naturally occurring Erythrina alkaloids. The conversion of 84 into 90 is believed to follow the pathway outlined in Scheme 18 . The initially formed $\alpha$-thiocarbocation intermediate generated from the Pummerer reaction of $\mathbf{8 4}$ is intercepted by the adjacent imido carbonyl to produce the $\alpha$-amido substituted furan $\mathbf{8 5}$. This transient intermediate undergoes a subsequent intramolecular DielsAlder cycloaddition across the tethered $\pi$-bond to furnish cycloadduct 86. Nitrogen-assisted ring opening of the oxabicyclic bridge results in the formation of zwitterionic intermediate 87 which undergoes a 1,2-thioethyl shift followed by methoxide ion ejection. Cyclization of the diactivated-aromatic tether onto $\mathrm{N}$-acyliminium ion $\mathbf{8 9}$ ultimately provides the tetracyclic amide $\mathbf{9 0}$. With a supply of 90 in hand, this enone was converted into the corresponding vinyl triflate which, in turn, was subjected to a palladium catalyzed formate reduction to give $\mathbf{9 1}$. The resulting thio-substituted diene was subsequently transformed into ketone $\mathbf{9 2}$ via a titanium mediated stamen 16 hydrolysis (Scheme 19) ${ }^{37}$. The present sequence constitutes<smiles>C=C(CCC(C)=O)C(=O)N(CCc1ccc(OC)c(OC)c1)C(=O)c1ccccc1CS(=O)CC</smiles>

78; $n=1$

$79 ; n=2$<smiles>COCC1(C(=O)OC)CC(=O)c2ccccc2[C@]12C(=O)CCc1cc(OC)c(OC)cc12</smiles>

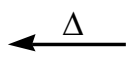

82; $n=1$

83; $n=2$

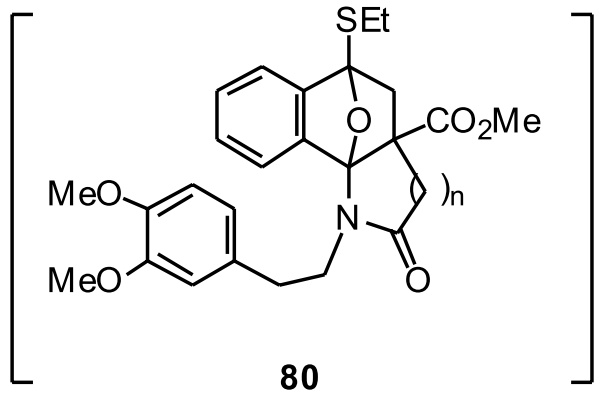<smiles>[Y][Y](=C)CC</smiles><smiles>COc1ccc(CC[N+]2([O-])C(=O)CC(C(C)=O)(C(C)=O)OC2=O)cc1OC</smiles>

Scheme 17. 


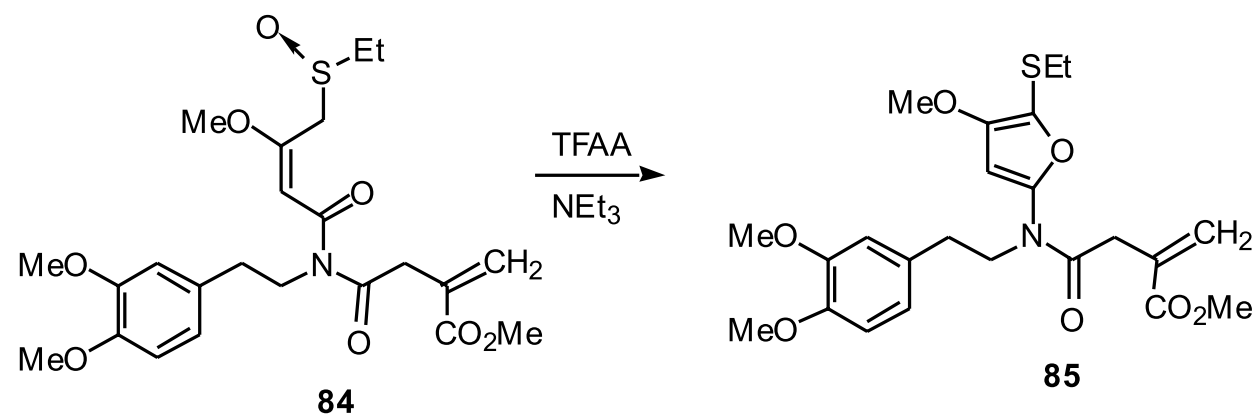

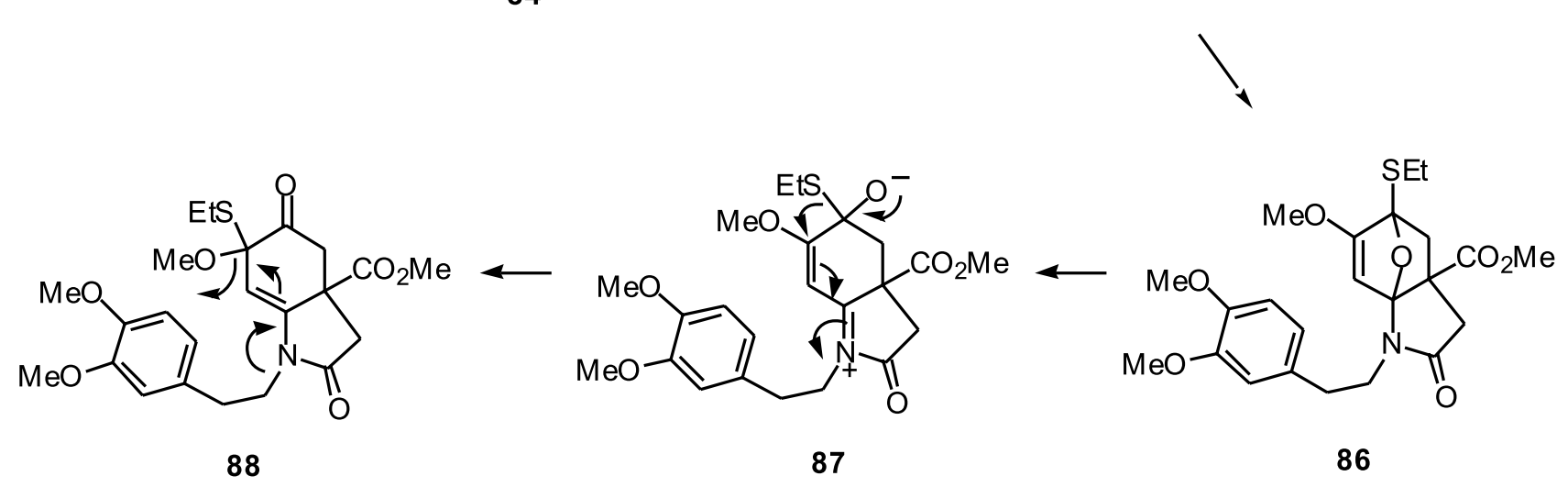

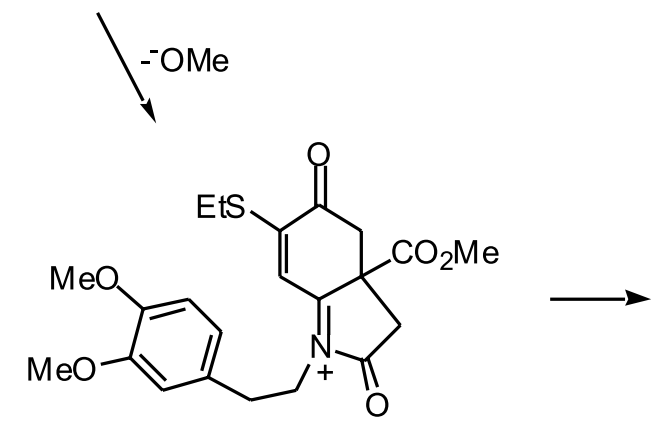

89<smiles>CCCCC1(C)CC(=O)C(CC)=C[C@]12c1cc(OC)c(OC)cc1CCN2C(=O)OC</smiles>

90

Scheme 18.

a formal synthesis of ( \pm )-erysotramidine (93) based on the successful conversion of $\mathbf{9 2}$ into $\mathbf{9 3}$ by Tsuda and coworkers $^{38}$

More recently, we developed a method for preparing cyclic 5-thio-2-amido-furans since functionalized furans of this sort allow for the ready access of a variety of novel azapolycyclic ring systems ${ }^{39}$. The method consisted of a Pummerer induced cyclization of imido dithioacetals of type 97 (Scheme 20). The starting substrates were prepared by the mixed aldol reaction of the $N$-trimethylsilyl protected $\delta$-valerolactam 94 (or $\varepsilon$-caprolactam 95) with bis-(methylsulfanyl)-acetaldehyde 96. Quenching the reaction with acetic anhydride followed by aqueous workup provided the expected aldol product in high yield as a 4:1mixture of diastereomers. The cyclic lactams were acylated with various acid chlorides using powdered $4 \mathrm{~A}^{\circ}$ molecular sieves as a neutral acid scavenger ${ }^{40}$ to provide the corresponding imides 97 in $60-98 \%$ yield. It was known from earlier work in the literature that treatment of thioketals with dimethyl(methylthio)sulfonium tetrafluoroborate (DMTSF) causes the carbon-sulfur bond to become labile upon methylthiolation ${ }^{41}$. The initially formed alkylthiosulfonium ion easily dissociates to produce a thionium ion and methyl sulfide ${ }^{42}$. Cyclization of the Pummerer intermediate onto the amide carbonyl group first affords dihydrofuran $\mathbf{9 8}$ which undergoes a subsequent elimination of acetic acid to give the cyclic 2-thioamidofuran system 99 in high overall yield.

With a satisfactory method for the synthesis of the cycloaddition precursors in place, we examined the DielsAlder reaction of the $\mathrm{N}$-yl-but-3-en-1-one substituted amidofuran $100(\mathrm{n}=1)$. Thermolysis of $\mathbf{1 0 0}$ at $110{ }^{\circ} \mathrm{C}$ 
<smiles>COC[C@]12CC(=O)C([As])=C[C@]13c1cc(OC)c(OC)cc1CCN3C(=O)C2</smiles>

90<smiles>COc1cc2c(cc1OC)[C@@]13CCN2C(=O)C=C1C=CC(OC)C3</smiles>

93<smiles>COc1cc2c(cc1OC)[C@@]13C=C([As])C=C[C@]1(OC)CC(=O)N3CC2</smiles>

91<smiles>CCN1c2cc(OC)c(OC)cc2[C@@]23CC(=O)C=C[C@]2(COC)C1CC3=O</smiles>

92

Scheme 19.

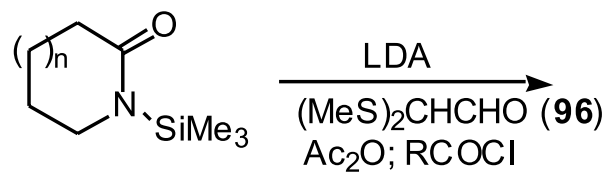

94; $\mathrm{n}=1$

$95 ; n=2$<smiles>[R]C(=O)N1CCCCC1</smiles><smiles>CC[C@H]1CCCCO1</smiles>

99; $\mathrm{R}=-\left(\mathrm{CH}_{2}\right)_{\mathrm{n}} \mathrm{CX}=\mathrm{CH}_{2}$

$\mathrm{X}=\mathrm{H}, \mathrm{CO}_{2} \mathrm{Me}$, aryl $70-82 \%$<smiles>[R]C(=O)N1CCCC(C(OC(C)=O)C(C)C)C1=O</smiles>

97

|DMTSF<smiles>[R]C(=O)N1CCCC2=C1OC(C)C2OC(C)(C)C</smiles>

98 
furnished the rearranged hexahydropyrroloquinolin-2-one 106 as the only isolable product in $92 \%$ yield as a 3:2mixture of diastereomers after silica gel chromatography (Scheme 21) ${ }^{43}$. Dethiomethylation occurred smoothly when a sample of $\mathbf{1 0 6}$ was subjected to Raney-nickel reduction in $95 \%$ ethanol producing $\mathbf{1 0 7}$ in $85 \%$ yield. In contrast to the above result, thermolysis of the homologous $N$-yl-pent4-en-1-one amidofuran 101 gave phenol 104 in $82 \%$ yield. In both cases, the initially formed oxo-bridged cycloadducts (i.e., 102 or 103) could not be isolated, as they readily underwent ring opening to produce the observed products. Furan 101, with the longer five-carbon tether, required more forcing conditions $\left(200^{\circ} \mathrm{C}\right)$ for the Diels-Alder cycloaddition and this resulted in the formation of phenol 104. Presumably, the initially formed cycloadduct $\mathbf{1 0 3}$ underwent ring opening/ thiomethyl migration but this was followed by elimination of methanethiol at the higher temperatures employed.

Because electron-withdrawing substituents on the $\pi$ bond exhibit a powerful influence on the rate of HOMOdienyl [4+2]-cycloadditions ${ }^{44}$, a study of the thermal behavior of the 2-carbomethoxy substituted alkenyl amidofuran 108 appeared to us to be a worthwhile goal. Indeed, incorporation of this activating substituent on the alkenyl $\pi$-bond greatly facilitated the cycloaddition and it was possible to isolate the Diels-Alder adduct $\mathbf{1 0 9}$ as a single diastereomer in $45 \%$ yield simply by stirring a sample of $\mathbf{1 0 8}$ in benzene at $25{ }^{\circ} \mathrm{C}$ (Scheme 22). The structure of $\mathbf{1 0 9}$ was firmly established by X-ray crystallography which revealed an anti-stereochemical relationship between the carbomethoxy group and oxygen bridge. The formation of this endo-cycloadduct is in full accord with molecular mechanics calculations which show a large ground state energy difference between the two diastereomers. Heating a sample of $\mathbf{1 0 9}$ at $90{ }^{\circ} \mathrm{C}$ gave the rearranged hexahydropyrroloquinolinone $\mathbf{1 1 0}$ in $78 \%$ yield as a 1:1-mixture of diastereomers.

To further illustrate the viability of this sequence as a practical strategy for the synthesis of complex polyazacyclic systems, we studied the cycloaddition behavior of the related amidofuran 111. We were gratified to find that heating 111 at $110^{\circ} \mathrm{C}$ for $2 \mathrm{~h}$ gave the rearranged amide $\mathbf{1 1 2}$ as a single diastereomer in $80 \%$ yield (Scheme 23). The 1,2-thiomethyl shift that occurs from the transient Diels-Alder cycloadduct probably proceeds via an episulfonium ion and consequently only one diastereomer would be expected ${ }^{45}$. Further transformations of $\mathbf{1 1 0}$ and 112 using the existing functional groups to establish additional stereogenic centers are currently underway.

In conclusion, our investigations have shown that many structurally diverse heterocyclic compounds can be easily accessed via the domino Pummerer/ cycloaddition/N-

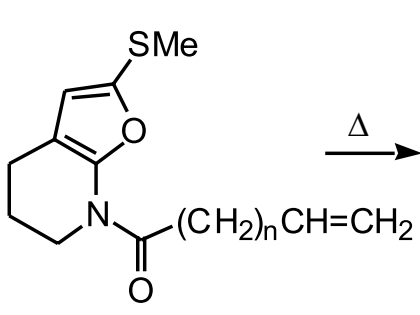

$100 ; n=1$

$101 ; n=2$

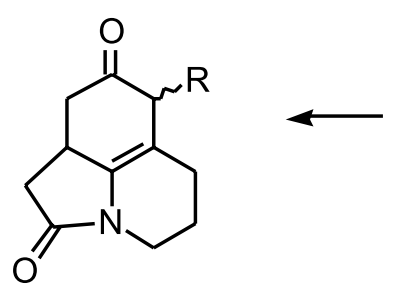

106; $\mathrm{R}=\mathrm{SMe}$

107; $\mathrm{R}=\mathrm{H}$
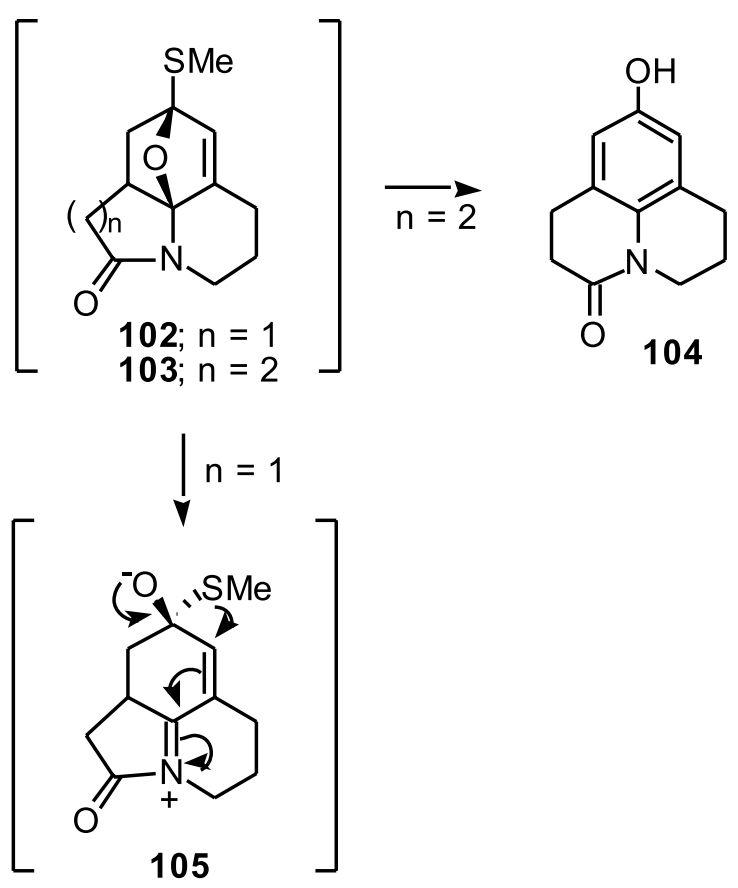

Scheme 21. 
<smiles>C=C(COC)CC(=O)N1CCCc2cc(C)oc21</smiles>

108

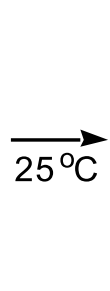

$\mathrm{MeO}_{2}$

109<smiles>COC[C@]12CC(=O)[C@H](C)C3=C1N(CCC3)CC2=O</smiles>

110

Scheme 22.<smiles>CC(=O)C1=CCCC1CC(=O)N1CCCc2cc(C)oc21</smiles>

111<smiles>COC(=O)[C@H]1C(=O)[C@H](C)C2=C3CCCC(=C31)[C@H]2C(C)=O</smiles>

112

Scheme 23.

acyliminium ion cyclization cascade. The key step in this process involves the generation of an amino-substituted furan by a Pummerer induced cyclization reaction. After the Diels-Alder reaction occurs, the [4+2]-cycloadduct undergoes a subsequent fragmentation to generate a reactive $N$-acyliminium ion. This triple cascade is applicable toward the preparation of a broad range of alkaloids. It is a reasonable expectation that future years will see a continued evolution of this unique domino cascade toward other synthetic targets.

Acknowledgment: We thank the National Institute of Health for financial support.

\section{References}

1. Russell, G. A.; Mikol, G. J. In Mechanisms of Molecular Migration; Thyagaragan, B. S., Ed.; Wiley Interscience: New York, 1968; Vol. 1, pp 157-207.

2. DeLucchi, O.; Miotti, U.; Modena, G. Organic Reactions; Paquette, L. A., Ed.; John Wiley: New York, 1991: Chap. 3, pp 157-184.

3. Grierson, D. S.; Husson, H. P. In Comprehensive Organic Synthesis; Trost, B. M., Ed.; Pergamon: Oxford, 1991; Vol. 6, pp 909-947.

4. Kennedy, M.; McKervey, M. A. In Comprehensive Organic Synthesis; Trost, B. M., Ed.; Pergamon: Oxford, 1991; Vol. 7, pp 193-216.
5. a) Oae, S.; Numata, T.The Pummerer Type of Reactions, In Isotopes in Organic Chemistry; Buncel, E.; Lee, C. E., Eds.; Elsevier: New York, 1980; Vol. 5, Chap. 2; b) Oae, S.; Numata, T.; Yoshimura, T. Heterosulphonium Salts, In The Chemistry of the Sulphonium Group Stirling, C. J. M.; Patai, S. Eds.; John Wiley \& Sons: New York, 1981.

6. Marino, J. P. Topics in Sulfur Chemistry; Senning, A., Ed.; George Thieme: Stuttgart, 1976; Vol. 1, p 1.

7. Bates, D. K. J. Org. Chem. 1977, 42, 3452.

8. Oikawa, Y.; Yonemitsu, O. J. Org. Chem. 1976, 41, 1118.

9. Ishibashi, H.; Harada, S.; Okada, M.; Ikeda, M.; Ishiyami, K.; Yamashita, H.; Tamura, Y. Synthesis 1986, 847.

10. Takano, S.; Iida, H.; Inomata, K.; Ogasawara, K. Heterocycles 1993, 35, 47.

11. Padwa, A.; Weingarten, M. D. Chem. Rev. 1996, 96, 223.

12. Padwa, A.; Gunn, D. E.; Osterhout, M. H. Synthesis 1997, 1353

13. a) Ho, T. -L. Tandem Organic Reactions; WileyInterscience: New York, 1992; b) Wender, P. A., Ed.; Frontiers in Organic Synthesis, Chem. Rev. 1996, 96, pp 1-600; c) Tietze, L. F.; Beifuss, U. Angew. Chem., Int. Engl. 1993, 32, 131.

14. Sutherland, J. K. In Comprehensive Organic Synthesis, Trost, B. M.; Fleming, I., Eds.; Pergamon: Oxford, 1991; Vol. 3, p 341. 
15. a) Canonne, P.; Boulanger, R.; Bernatchez, M. Tetrahedron Lett. 1987, 28, 4997; b) Curran, D. P. In Comprehensive Organic Synthesis, Trost, B. M., Fleming, I., Eds.; Pergamon Press: Oxford, 1991; Vol. 4, Chapter 4.2; c) Davies, H. M. L.; Clark, T. J.; Smith, H. D. J. Org. Chem. 1991, 56, 3817; d) Grigg, R.; Kennewell, P.; Teasdale, A. J. Tetrahedron Lett. 1992 , 33, 7789.

16. Padwa, A.; Hennig, R.; Kappe, C. O.; Reger, T. S. J. Org. Chem. 1998, 63, 1144.

17. Padwa, A.; Waterson, A. G. Tetrahedron Lett. 1998 , $39,8585$.

18. Padwa, A.; Waterson, A. G. Tetrahedron 2000, 56, 10159.

19. a) Kita, Y.; Yasuda, H.; Tamura, O.; Itoh, F.; Tamura, Y. Tetrahedron Lett. 1984, 25, 4681; b) Kita, Y.; Tamura, O.; Miki, T.; Tamura, Y Tetrahedron Lett. 1987, 28, 6479.

20. Kita, Y.; Tamura, O.; Shibata, N.; Miki, T. Chem. Pharm. Bull. 1990, 38, 1473.

21. Trost, B. M.; Murayama, E. J. Am. Chem. Soc. 1981, $103,6529$.

22. Bkakuni, D. S.; Jain, S. "Protoberberine Alkaloids" in The Alkaloids: Chemistry and Pharmacology; Brossi, A., Ed.; Academic Press: Orlando, 1985; Vol. 26, p 229.

23. Kametani, T. in The Total Synthesis of Natural Products; ApSimon, J., Ed.; John Wiley and Sons: New York, 1977; Vol. 3, pp 1-272.

24. a) Cushman, M.; Dekow, F. W.; Jacobsen, L. B. J. Med. Chem. 1979, 22, 331; b) Memetzidis, G.; Stambach, J. F.; Jung, L.; Schott, C.; Heitz, C.; Stoclet, J. C. Eur. J. Med. Chem. 1991, 26, 605.

25. Matulenko, M. A.; Meyers, A. I. J. Org. Chem. 1996, $61,573$.

26. Zhang, J. S.; Le Men-olivier, L.; Massiot, G. Phytochemistry 1995, 39, 439.

27. Gesson, J.; Jacquesy, J.; Rambaud, D. Tetrahedron 1993, 49, 2239.

28. Mooradian, A.; Cavallito, C. J.; Bergman, A. J.; Lawson, E. J.; Suter, C. M. J. Am. Chem. Soc. 1949, $71,3372$.

29. Denmark, S. E. In Comprehensive Organic Synthesis; Trost, B. M.; Fleming, I., Eds.; Pergamon Press: Oxford, 1991; Vol. 5, pp 751-784.

30. a) Overman, L. E.; Ricca, D. J. In Comprehensive Organic Synthesis; Trost, B. M.; Fleming, I., Eds.;
Pergamon Press: 1991; Vol. 2, pp 1007-1046; b) Overman, L. E. Acc. Chem. Res. 1992, 25, 352.

31. Fleming, I.; Dunogues, J.; Smithers, R. "The Electrophilic Substitution of Allylsilanes and Vinylsilanes " In Organic Reactions; Kende, A. S., Ed.; John Wiley and Sons: New York, 1989; Vol. 37, Chapter 2, p 57.

32. a) De Groot, A.; Jansen, B. J. M. J. Org. Chem. 1984, 49, 2034; b) Jansen, B. J. M.; Bouwman, C. T.; De Groot, A.Tetrahedron Lett. 1994, 35, 2977.

33. a) Cochran, J. E.; Padwa, A. Tetrahedron Lett. 1995, 36, 3495; b) Cochran, J. E.; Padwa, A. J. Org. Chem. 1995, 60, 3938; c) Padwa, A.; Cochran, J. E.; Kappe, C. O. J. Org. Chem. 1996, 61, 3706.

34. a) Kappe, C. O.; Padwa, A. J. Org. Chem. 1996, 61, 6166; b) Padwa, A.; Kappe, C. O.; Cochran, J. E.; Snyder, J. P. J. Org. Chem. 1997, 62, 2786.

35. a) Padwa, A.; Kappe, C. O.; Reger, T. S. J. Org. Chem. 1996, 61, 4888; b) Padwa, A.; Hennig, R.; Kappe, C. O.; Reger, T. S. J. Org. Chem. 1998, 63, 1144.

36. Hill, R. K.; In The Alkaloids; Manske, R. H. F., Ed.; Academic Press: New York, 1967; Vol. 9, p 483.

37. Mukaiyama, T.; Kamio, K.; Kobayashi, S.; Takei, H. Bull. Chem. Soc. Jpn. 1972, 45, 3723.

38. Tsuda, Y.; Hosoi, S.; Nakai, A.; Sakai, Y.; Abe, T.; Ishi, Y.; Kiuchi, F.; Sano, T. Chem. Pharm. Bull. 1991, 39, 1365.

39. Padwa, A.; Ginn, J. D.; McClure, M. S. Organic Lett. 1999, $1,1559$.

40. Weinstock, L.; Karady, S.; Roberts, F.; Hoinowski, A.; Brenner, G.; Lee, T.; Lumma, W.; Sletzinger, M. Tetrahedron Lett. 1975, 16, 3979.

41. a) Trost, B. M.; Sato, T. J. Am. Chem. Soc. 1985, 107, 719; b) Rice, J. L.; Favstritsky, N. A. J. Am. Chem. Soc. 1969, 91, 1751.

42. a) Smallcombe, S. H.; Caserio, M. C. J. Am. Chem. Soc. 1971, 93, 5826; b) Kim, J. K.; Pau, J. K.; Caserio, M. C. J. Org. Chem. 1979, 44, 1544.

43. Padwa, A.; Ginn, J. D.; Lynch, S. M. Tetrahedron Lett. 2000, 41, 9385.

44. Fleming, I. Frontier Orbitals and Organic Chemical Reactions; Wiley-Interscience: New York, 1976.

45. Nicolaou, K. C.; Ladduwahetty, T.; Randall, J. L.; Chucholowski, A. J. Am. Chem. Soc. 1986, 108, 2466.

Received: June 6, 2001 Published on the web: August 15, 2001 